\title{
Guidelines for Optimization of the Absorber Layer Energy Gap for High Efficiency $\mathrm{Cu}(\mathrm{In}, \mathrm{Ga}) \mathrm{Se}_{2}$ Solar Cells
}

\author{
N. Severino, N. Bednar, N. Adamovic \\ Institute of Sensor and Actuator Systems, Technische Universität Wien, Vienna, Austria \\ Email: noemi.severino@tuwien.ac.at
}

How to cite this paper: Severino, N., Bednar, N. and Adamovic, N. (2018) Guidelines for Optimization of the Absorber Layer Energy Gap for High Efficiency $\mathrm{Cu}(\mathrm{In}, \mathrm{Ga}) \mathrm{Se} 2$ Solar Cells. Journal of Materials Science and Chemical Engineering, 6, 147-162.

https://doi.org/10.4236/msce.2018.64015

Received: February 15, 2018

Accepted: April 27, 2018

Published: April 30, 2018

Copyright $\odot 2018$ by authors and Scientific Research Publishing Inc. This work is licensed under the Creative Commons Attribution International License (CC BY 4.0).

http://creativecommons.org/licenses/by/4.0/

(c) (i) Open Access

\begin{abstract}
This work investigates in-depth the effects of variation of the compositional ratio of the absorber layer in $\mathrm{Cu}(\mathrm{In}, \mathrm{Ga}) \mathrm{Se}_{2}$ (CIGS) thin-film solar cells. Electrical simulations were carried out in order to propose the most suitable gallium double-grading profile for the high efficiency devices. To keep the model as close as possible to the real behavior of the thin film solar cell a trap model was implemented to describe the bulk defects in the absorber layer. The performance of a solar cell with a standard CIGS layer thickness $(2 \mu \mathrm{m})$ exhibits a strong dependence on the front grading height (decreasing band gap toward the middle of the CIGS layer). An absolute gain in the efficiency (higher than $1 \%$ ) is observed by a front grading height of 0.22 . Moreover, simulation results show that the position of the plateau (the region characterized by the minimum band gap) should be accurately positioned at a compositional ratio of $20 \% \mathrm{Ga}$ and $80 \% \mathrm{In}$, which corresponds to the region where a lower bulk defect density is expected. The developed model demonstrates that the length of the plateau is not playing a relevant role, causing just a slight change in the solar cell performances. Devices with different absorber layer thicknesses were simulated. The highest efficiency is obtained for a CIGS thin film with thicknesses between 0.8 and $1.1 \mu \mathrm{m}$.
\end{abstract}

\section{Keywords}

Solar Cell, Thin-Film, Simulation, Material Modelling

\section{Introduction}

Among thin-film technologies, solar cells and modules based on the polycrystalline $\mathrm{Cu}(\mathrm{In}, \mathrm{Ga}) \mathrm{Se}_{2}$ (CIGS) absorber layer are one of the most advanced and effi- 
cient. Efficiencies higher than $22 \%$ have been reported on the cell level [1]. The module efficiencies around 19\% have been measured and confirmed under standard conditions (AM1.5 spectrum at $25^{\circ} \mathrm{C}$ ) [1].

CIGS is a versatile material and products based on this semiconductor can access different markets. On one side CIGS glass-encapsulated modules can answer the demand of the well-established PV market based on classical PV applications (e.g. power plants and roof-top installations). On the other side there are significant efforts to develop flexible, lighter and durable modules with better integration capabilities, for the emerging applications in building and product integrated PV.

What makes CIGS an attractive absorber layer compared to silicon, is that it is a direct band gap material characterized by a high absorption coefficient, which allows the decrease of the absorber layer thickness; high stability and high efficiency devices with thicknesses between $1-2 \mu \mathrm{m}$ can be readily obtained [2].

CIGS thin film can be grown using different vacuum and non-vacuum techniques (e.g. evaporation, sputtering, electrochemical deposition, nanoparticle printing and ion-beam deposition) [3] [4] [5] [6] [7]. Devices with the highest performances are fabricated by a multi-stage co-evaporation process, known as the "three-stage process" [8]. This deposition technique results in a double-graded composition profile characterized by higher Ga content towards the back and the front of the film, and a plateau of low Ga content in between [9] [10]. Such controlled variable semiconductor composition represents an attractive possibility to tune the semiconductor's band gap, which can be graded over a wide range by varying the $[\mathrm{Ga}] /([\mathrm{In}]+[\mathrm{Ga}])$ ratio in the thin film layer during the growth process [11] [12] [13].

However, besides its interesting properties, this semiconductor compound results in a complex structure, due to the large number of layers those constitute the final solar cell. In order to allow the selection of the most suitable solar cell structure, which is able to achieve higher conversion efficiencies and to fully understand the fundamental physics behavior of the device, it is needed to develop numerical models which will include the described peculiarities of the material. Simulations based upon these models will reduce the number of technological experiments and enable faster and inexpensive optimization of the devices.

In this paper we analyzed and reviewed the most suitable characteristics of the CIGS absorber layer in order to reach high efficiency devices. In particular an in-depth analysis of gallium double-grading strategy was carried out. Thus, it can provide the support to the technology development.

\section{Simulation Set-Up}

In the simulation work SCAPS-1D [14] software was used. Steady-state band diagrams, recombination profiles, and carrier transport were calculated using this software, solving Poisson equation together with hole and electron continuity equations [15]. The device architecture of the simulated CIGS solar cell consists 
of the following layers: substrate (glass or polyimide)/Mo/CIGS/CdS/TCO.

Two layers of $\mathrm{ZnO}$ and $\mathrm{ZnO}$ : $\mathrm{Al}$ form the transparent conductive oxide (TCO) of the solar cell. Characterized by high band gaps, these materials are transparent to the most of the solar spectrum. The chemical bath deposited CdS film is employed as buffer layer in the high efficiency CIGS solar cell [16] [17]. This material can uniformly and entirely cover the rough surface of the CIGS film avoiding the formation of shunt paths [18]. Additionally, the use of a buffer layer leads to the creation of an efficient p-n junction in CIGS/CdS/ZnO. A favorable band alignment can be observed when a CdS buffer layer is used [19] [20] [21]. A thin CIGS film, serves as the absorber (photoactive) layer. Mo was used as the back electrode. A part of the Mo layer is converted to $\mathrm{MoSe}_{2}$ when CIGS layer is deposited at high temperature. The $\mathrm{MoSe}_{2}$ contributes to the improvement of adhesion at the CIGS/Mo interface and plays a significant role in the formation of a favorable ohmic contact [22]. A summary of the physical parameters used in the model is shown in Table 1. The device architecture of the simulated CIGS solar cell is presented in Figure 1(a), Figure 1(b) shows an SEM analysis of cross section of the device.

Considering initially a uniform band-gap (Eg) CIGS solar cell with an absorber layer thickness of $2 \mu \mathrm{m}$, the Eg was uniformly varied within the whole absorber layer depth according to Equation (1) [23].

Table 1. Summary of the physical parameters used for the simulation model.

\begin{tabular}{|c|c|c|c|}
\hline \multirow{2}{*}{ Parameters } & \multicolumn{3}{|c|}{ Layers } \\
\hline & CIGS & CdS & $\mathrm{ZnO}$ \\
\hline Thickness (nm) & 2000 & 50 & 80 \\
\hline Bangap (eV) & $1.0-1.6^{*}$ & 2.4 & 3.3 \\
\hline Electron affinity $(\mathrm{eV})$ & $4.5-3.9$ & 4.45 & 4.6 \\
\hline Dielectric constant & $15-10$ & 10 & 9.0 \\
\hline Electron mobility $\left(\mathrm{cm}^{2} / \mathrm{Vs}\right)$ & 100 & 100 & 100 \\
\hline Hole mobility $\left(\mathrm{cm}^{2} / \mathrm{Vs}\right)$ & 25 & 25 & 25 \\
\hline Density of states in $\mathrm{CB}\left(\mathrm{cm}^{-3}\right)$ & $1 \times 10^{18}$ & $1 \times 10^{18}$ & $1 \times 10^{18}$ \\
\hline Density of states in VB $\left(\mathrm{cm}^{-3}\right)$ & $1 \times 10^{19}$ & $1 \times 10^{19}$ & $1 \times 10^{19}$ \\
\hline Shallow donor conc. $\left(\mathrm{cm}^{-3}\right)$ & - & $1 \times 10^{18}$ & $1 \times 10^{17}$ \\
\hline Shallow acceptor conc. $\left(\mathrm{cm}^{-3}\right)$ & $\begin{array}{c}4.1015,3.1015 \\
6.1015[16]\end{array}$ & - & - \\
\hline Radiative recombination $\left(\mathrm{cm}^{3} \cdot \mathrm{s}^{-1}\right)$ & $1 \times 10^{-10}$ & $1 \times 10^{-10}$ & $1 \times 10^{-10}$ \\
\hline Surface recombination velocity $\left(\mathrm{cm} \cdot \mathrm{s}^{-1}\right)$ & $1 \times 10^{6}(\mathrm{back})$ & - & - \\
\hline Defect type & Donor & Acceptor & Acceptor \\
\hline Defect distribution & Ga-dep.* & Uniform & Uniform \\
\hline Defect density $\left(\mathrm{cm}^{-3}\right)$ & $(\text { see Figure } 2)^{*}$ & $6 \times 10^{17}$ & $1 \times 10^{16}$ \\
\hline Defect capture cross section e- $\left(\mathrm{cm}^{2}\right)$ & $1 \times 10^{-15}$ & $1 \times 10^{-15}$ & $1 \times 10^{-15}$ \\
\hline Defect capture cross section $\mathrm{h}\left(\mathrm{cm}^{2}\right)$ & $5 \times 10^{-13}$ & $5 \times 10^{-13}$ & $5 \times 10^{-13}$ \\
\hline
\end{tabular}

*Dependent on Ga concentration. 


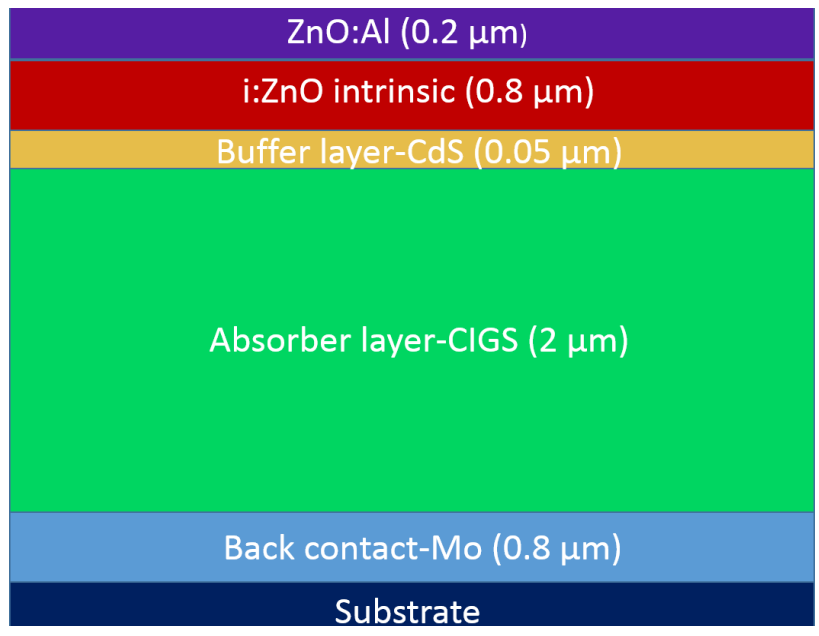

(a)

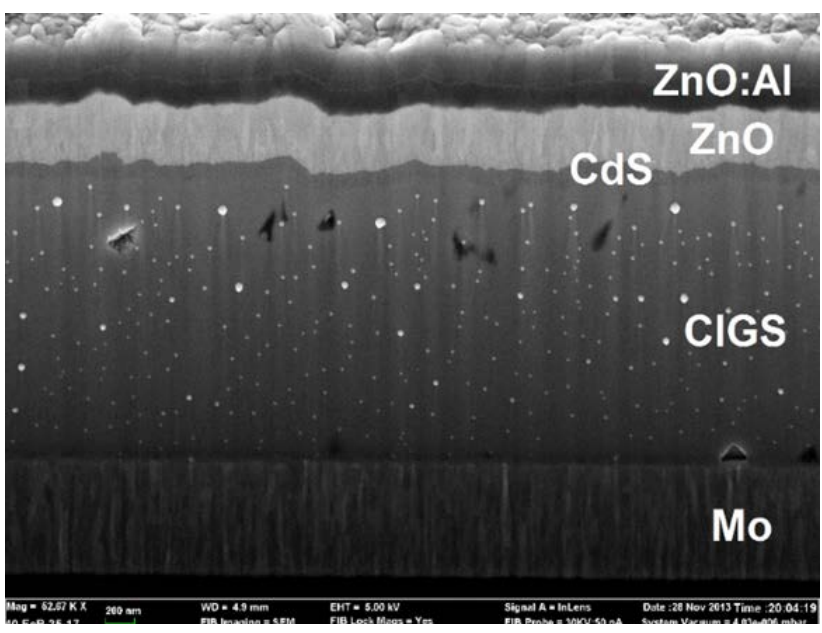

(b)

Figure 1. (a) Device architecture of the simulated CIGS solar cell; (b) Cross-section of the CIGS solar cell, obtained by SEM.

$$
\mathrm{E}_{\mathrm{g}}^{\mathrm{CIGS}}=\mathrm{E}_{\mathrm{g}}^{\mathrm{CIS}}(1-\mathrm{GGI})+\mathrm{GGI} \cdot \mathrm{E}_{\mathrm{g}}^{\mathrm{CGS}}-b \cdot \mathrm{GGI}(1-\mathrm{GGI})
$$

where $\mathrm{E}_{\mathrm{g}}^{\mathrm{CIS}}=1.01 \mathrm{eV}$ and $\mathrm{E}_{\mathrm{g}}^{\mathrm{CGS}}=1.636 \mathrm{eV}$ are band-gaps of CIS and CGS, respectively; GGI $=[\mathrm{Ga}] /([\mathrm{Ga}]+[\mathrm{In}])$ and represents the compositional ratio and $b$ is the optical bowing coefficient. Values between 0.11 and 0.24 have been reported for this parameter [17].

The effects of the change of the Ga content in the absorber layer on the solar cell physical parameters were also considered in the model. Due to the lack of data in literature regarding the effect of the variation of the compositional ratio on the dielectric constant $(\varepsilon)$ and electron affinity $(\chi), \varepsilon$ and $\chi$ were assumed to vary linearly with the variation of the Ga composition [24]. On the other side, mobility $(\mu)$ was assumed to be independent of the composition [25]. This choice was made based on the results reported in [24] [26], where it was found that the room temperature mobility remains nearly constant while varying the Ga content. A change of the CIGS absorption coefficient $(\alpha)$ caused by the varia- 
tion of the compositional ratio was also considered. The data reported in the work of Paulson et al. [27], regarding the measured a values for different Ga contents, were implemented in the simulations.

In order to improve the accuracy of the model, the variation of the Ga ratio in the absorber layer and its influence on the CIGS trap concentration was taken into account. A trap model based on the works reported in [25] [28] was used, which considers the dominant ( $\mathrm{Cu}$ antisite) defects within CIGS composite. The dependence of these defects (traps) concentration on the Ga compositional ratio is shown in Figure 2.

In this model, the trap concentration is around $6 \times 10^{14} \mathrm{~cm}^{-3}$ for the compositional ratio GGI $=0$ and decreases to $1 \times 10^{14} \mathrm{~cm}^{-3}$ for GGI $=0.2$. Above GGI $=0.2$ (for Eg higher than $1.14 \mathrm{eV}$ ) the trap concentration is characterized by a quick and sharp increase, reaching values around $1 \times 10^{17} \mathrm{~cm}^{-3}$ at GGI close to 1 . This experimental data is based on a standard three stage growth process of the absorber layer. In order to model the traps concentration at GGI $=1$, the values reported in [28] were used. These values are based on a single-step co-evaporation process of growth. We can consider this approximation reliable, since the differences of the effects of the defects concentration with the Ga composition for a three- or a one-stage process are worthy of consideration just in the compositional ratio range between GGI $=0.2$ and GGI $=0.3$ [28]. In this area the trap density is lower when a three stage process is used for the absorber preparation. Using the experimental data reported in [25] [28] bulk traps with an activation energy that was maintained constant for all the different Ga compositions were considered in the model.

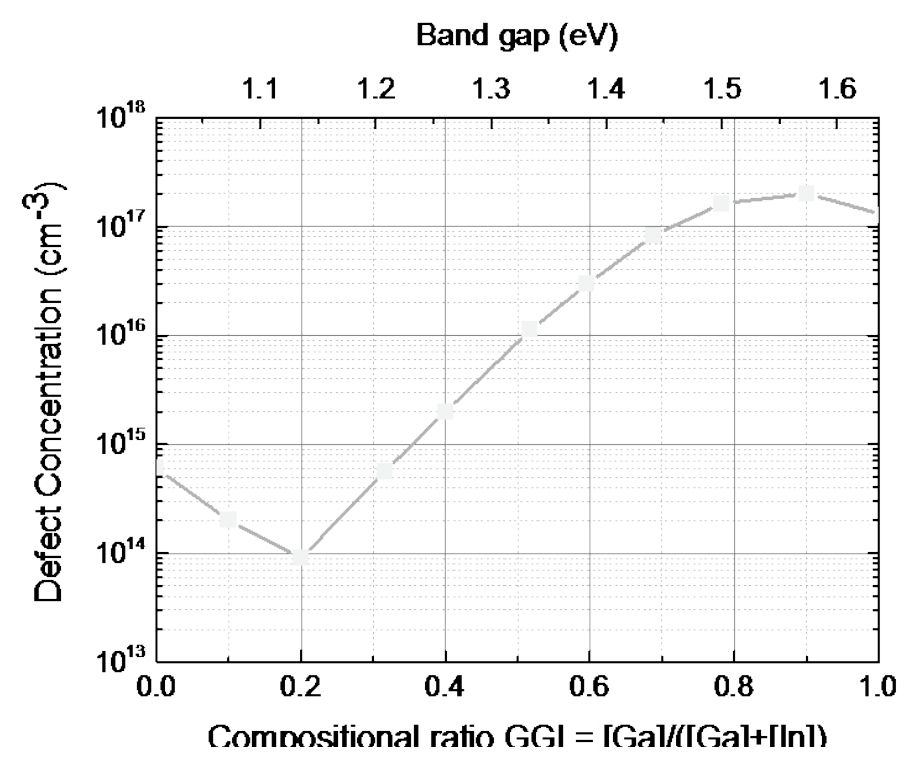

Figure 2. Variation of the traps (defects) concentration with Ga composition implemented in the model in order to model bulk defects in the absorber layer [25]. Reproduced with permission from IEEE Proceedings Photovoltaic Specialists Conference (PVSC), 2010 35th IEEE, pp. 2488-2492 (2010). Copyright 2010 IEEE. 


\section{Uniform Band Gap}

In order to validate the parameters in the model set-up, the dependence of the device performances on the band-gap energy was investigated considering initially a uniform band-gap. The main effect expected and observed by the change of GGI in the CIGS layer is the shift of the conduction band (CB) minimum [29] [30].

Current-voltage (I-V) simulations were carried out using the trap model described above. The resulting main solar cell parameters: open circuit voltage $\left(\mathrm{V}_{\mathrm{OC}}\right)$, short circuit current $\left(\mathrm{J}_{\mathrm{SC}}\right)$, fill factor $(\mathrm{FF})$ and efficiency $(\eta)$ are presented in Figure 3.

The results obtained with simulations are completely in agreement with what was observed experimentally [31]. The efficiency is not rising proportionally to the increase of the band gap but it rises only in the compositional range between GGI $=0.2$ and GGI $=0.3$. This behaviour can be explained considering that the defect density changes with the variation of the Ga content.

\section{Double Graded Band Gap and Its Optimization}

When a CIGS layer is produced, it is intrinsic to observe a double-grading of the
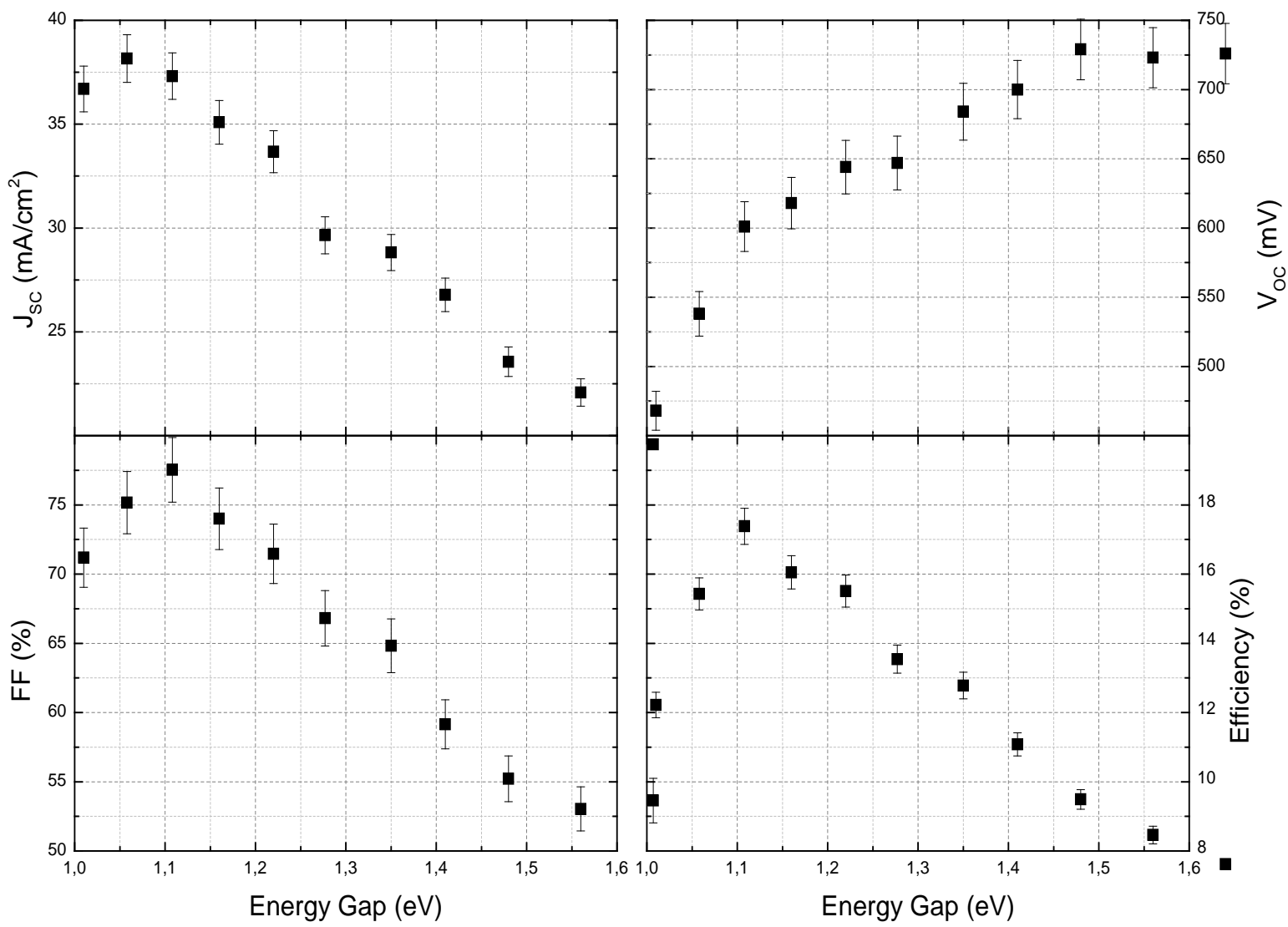

Figure 3. Dependence of the device performance parameters on the band-gap energy considering a uniform band-gap CIGS solar cell with an absorber layer thickness of $2 \mu \mathrm{m}$. 
compositional ratio in the absorber. The double grading is caused by an inadequate inter-diffusion of the intermediate phases that results in an increase of the $[\mathrm{Ga}] /([\mathrm{In}]+[\mathrm{Ga}])$ ratio both toward the back contact and the space charge region (SCR). Therefore a typical double-grading profile is formed, which exhibits a minimum amount of $\mathrm{Ga}$ in the middle layer region and an increased amount toward the CIGS/Mo and the CIGS/CdS interfaces in the absorber layer. A number of studies have already demonstrated the beneficial effects of the double-grading strategy on the solar cell efficiency [8] [32] [33].

In order to optimise a double-grading for an enhancement of the CIGS solar cell performance we started with the study of three different grading profiles measured and reported in [16]. The different profiles, experimentally assessed by secondary ion mass spectrometry (SIMS) by Chirilă et al. [16] are shown in Figure 4 (dot lines). Based on these SIMS curves the depth profiles reported in Figure 4 (solid lines) were obtained and implemented in the simulation model.

In order to better study the influence of the double grading, the depth-profiles of the three samples were simplified in three separate areas: a higher front grading (decreasing band gap toward the middle of the absorber layer), a plateau characterized by a uniform band gap, and a back-graded profile that reaches a maximum and then stabilizes (Figure 4).

The performances of the devices with the described Ga profiles (Figure 4) were analyzed by $\mathrm{I}-\mathrm{V}$ curve simulations, at the temperature of $300 \mathrm{~K}$ with the standard AMG1.5 spectrum and considering CIGS thickness of $2 \mu \mathrm{m}$. The simulations showed the best performances for sample C (the "green" line of Ga profile reported in Figure 4), as it was also reported in [16]. These simulation results were obtained considering the trap model for bulk defect density described in Section 2.1, which directly creates a relation between the trap concentration in

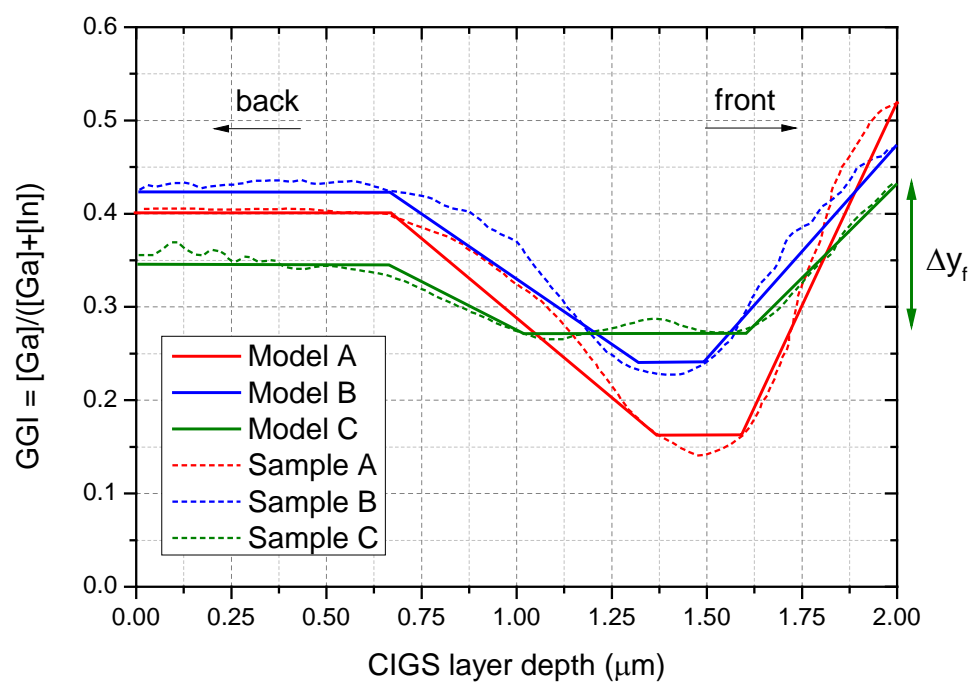

Figure 4. Ga profiles of three samples (A-C) from reference [16] showing the compositional ratio GGI along the CIGS layer depth (dot lines). Piecewise linear Ga depth profiles (solid lines) based on [16] are implemented in the model. 
the absorber layer and the Ga content. The solar cell parameters, extracted from the simulated I-V curve and reported in Table 2 are in good agreement with the experimental results of [16].

The possible reasons for the better performance of Sample C (based on the Ga grading profiles presented in Figure 4) which are considered in the further analysis are the following:

- The front grading height $\left(\Delta \mathrm{y}_{\mathrm{f}}\right)$ is less pronounced for sample $\mathrm{C}\left(\Delta \mathrm{y}_{\mathrm{f}}=0.16\right)$ than in the case of samples $A\left(\Delta y_{f}=0.38\right)$ and B $\left(\Delta y_{f}=0.25\right)$.

- The front grading in sample $C$ is exactly confined to the SCR. The Ga profile at the front of the absorber layer decreases until $1.6 \mu \mathrm{m}$, so considering Figure 4 for an overall depth of $0.4 \mu \mathrm{m}$ which represents the width of the space charge region, as it was confirmed by capacitance-voltage simulations. Hence, the front $\mathrm{Ga}$ profile does not extend beyond the space charge region. It is important to confine the front grading in this area, since a rise of Eg in the SCR will generate an additional electric field $\mathrm{E}$ that will work against the electric field of the $\mathrm{p}-\mathrm{n}$ junction retarding the transport of electrons. In principle, this effect could be detrimental for the performances of the device. Thus, in order to avoid the deterioration of the photo-current, the front grading should be confined to the SCR where the quasi-electric field E, produced by the band-gap variation, should be smaller than the field caused by the p-n junction. This will allow photo-generated electron-hole pairs to be separated without recombination avoiding a sharp decrease of the photo-current caused by the quasi-electric field $\mathrm{E}$.

- Sample C exhibits a plateau at a CIGS layer depth which corresponds to the region where the defects concentration approaches the minimum value (Figure 2). Therefore a lower bulk defect density is expected in this area.

\subsection{Effect of $\Delta y_{f}$}

In order to understand the effect of $\Delta y_{f}$ on the solar cell performances band diagram simulations at room temperature were carried out. The results are reported in Figure 5.

Band diagram simulations show that a larger front grading height results in a more evident notch in the CB (Sample A) as it is presented in Figure 5. This notch, already visible at $\mathrm{T}=300 \mathrm{~K}$, is situated just behind the space charge region. Simulations show that a larger value of $\Delta \mathrm{y}_{\mathrm{f}}$ results in larger barrier for electrons. The notch acts like a trap for electrons and its effect will be stronger at

Table 2. Solar cell main parameters of sample C, extracted from I-V curves, compared with measurement results reported in [16].

\begin{tabular}{ccccc}
\hline & \multicolumn{4}{c}{ Solar cell parameters } \\
\cline { 2 - 5 } & $\mathrm{V}_{\mathrm{OC}}(\mathrm{mV})$ & $\mathrm{J}_{\mathrm{SC}}\left(\mathrm{mA} / \mathrm{cm}^{2}\right)$ & $\mathrm{FF}(\%)$ & $\eta(\%)$ \\
\hline Measured [16] & 712 & 34.8 & 75.7 & 18.7 \\
Simulated & 710 & 35.0 & 75.2 & 18.7 \\
\hline
\end{tabular}




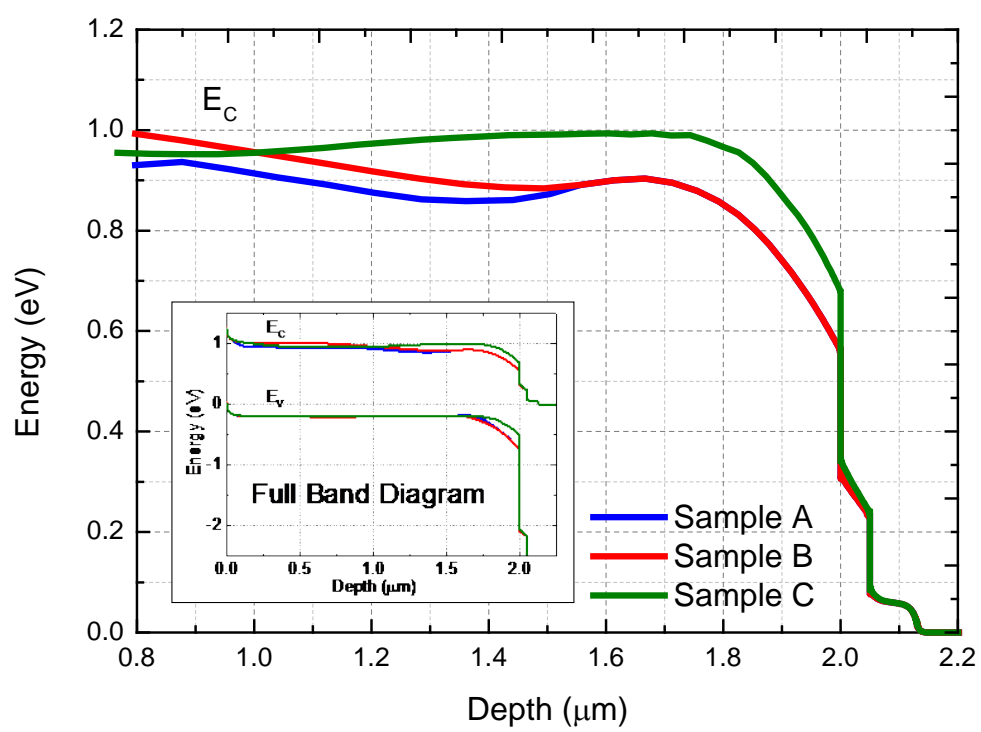

Figure 5. Band diagram simulations at $\mathrm{T}=300 \mathrm{~K}$ for the three different $\mathrm{Ga}$ profiles of samples $\mathrm{A}, \mathrm{B}$ and $\mathrm{C}$ with focus on the more prominent notch in the $\mathrm{CB}$ at around $1.5 \mu \mathrm{m}$, visible just behind the space charge region for the samples with a larger $\Delta \mathrm{y}_{\mathrm{f}}$ (Samples $\mathrm{A}$ and $\left.\mathrm{B}\right)$.

lower temperature when the thermal energy is not sufficient for the electrons to overcome the barrier. From these results it can be concluded that a steep Ga grading profile increases the recombination probability, due to the formation of this barrier behind the space charge region. From considerations reported above, we can conclude that the double grading profile of sample $\mathrm{C}$ is more suitable than of samples A and B.

Once demonstrated and studied the reason of better performances of Sample $\mathrm{C}$ and assuming the possibility to control the compositional ratio in the absorber layer with high precision, we carried out several simulations considering different $\mathrm{Ga}$ profiles based on sample $\mathrm{C}$ in order to extract the most suitable double-grading profile obtaining efficient CIGS solar cell. The simulated compositional ratios are reported in Figure 6(a) and the resulting I-V curves are shown in Figure 6(b). A summary of the solar cells parameters for the different Ga profiles are reported in Table 3.

As it can be observed from Table 3, the best solar cell efficiency is obtained for the sample 4 that presents a front grading height $\Delta \mathrm{y}_{\mathrm{f}}=0.22$, confined in the space charge region. The plateau region for this sample is positioned at CIGS layer depth of $1.63 \mu \mathrm{m}$ so exactly $0.37 \mu \mathrm{m}$ of distance from the CIGS/CdS interface, in the area in which a minimum defects density is expected according to the trap model reported in Figure 2. This sample presents the highest values for both $\mathrm{V}_{\mathrm{OC}}$ and $\mathrm{J}_{\mathrm{SC}}$. Due to the high thickness of the absorber layer $(2 \mu \mathrm{m})$, the grading at the back contact is playing a negligible role.

Preliminary simulations have also demonstrated that, in order to improve the solar cell performances, the position of the plateau in a region of minimum defects density is more relevant than the front grading height. Considering a fixed 

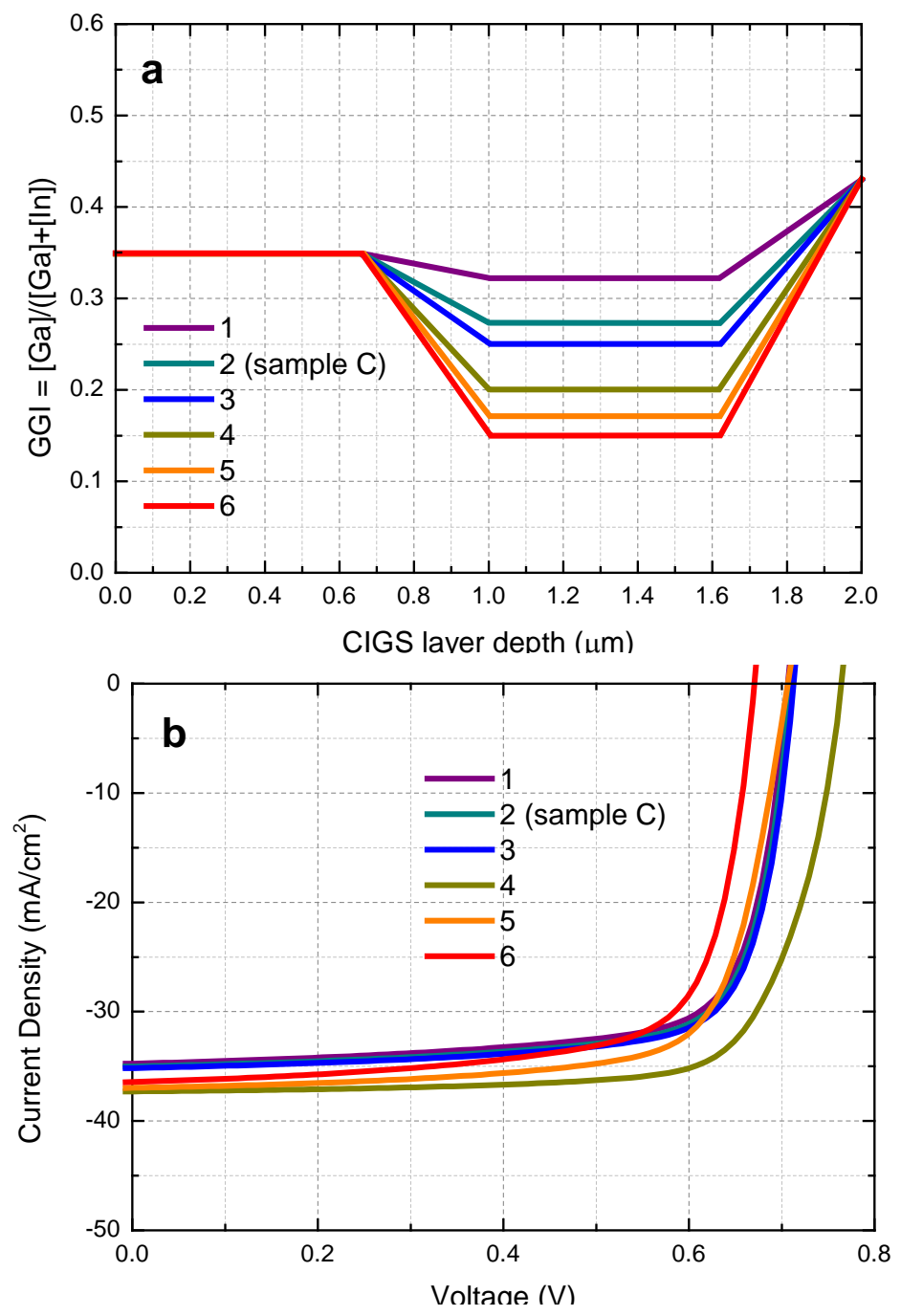

Figure 6. (a) Different Ga profiles implemented in the simulations in order to extract the most suitable front and back grading profiles; (b) Simulated I-V curves obtained using the different compositional ratio reported in Figure 6(a).

Table 3. Solar cells parameters for different front and double grading combinations extracted from simulated I-V curves reported in Figure 6(b).

\begin{tabular}{cccccc}
\hline & \multicolumn{5}{c}{ Solar cell parameters } \\
\cline { 2 - 6 } & $\mathrm{V}_{\mathrm{OC}}(\mathrm{mV})$ & $\mathrm{J}_{\mathrm{SC}}\left(\mathrm{mA} / \mathrm{cm}^{2}\right)$ & $\mathrm{FF}(\%)$ & $\eta(\%)$ & $\Delta \mathrm{y}_{\mathrm{f}}$ \\
\hline 1 & 707 & 34.75 & 74.75 & 18.4 & 0.11 \\
2 (sample C) & 710 & 35.01 & 75.2 & 18.7 & 0.16 \\
3 & 713 & 35.16 & 75.56 & 18.9 & 0.18 \\
4 & 764 & 37.3 & 75.20 & 21.4 & 0.22 \\
5 & 707 & 36.97 & 73.64 & 19.24 & 0.26 \\
6 & 671 & 36.43 & 72.30 & 17.67 & 0.28 \\
Sample with uniform & & & & & \\
defects distribution at & 602 & 37.2 & 77.5 & 17.4 & - \\
GGI = 0.2 (Figure 3) & & & & & \\
\hline
\end{tabular}


position for the plateau and changing just the front grading height an absolute change in the efficiency lower than $1 \%$ was observed. Simulation results for the highest performing device with uniform defect distribution at a GGI $=0.2$ (see Figure 3), which corresponds to minimum defects concentration, are reported for a comparisons in Table 3. The efficiency of the device with uniform defects distribution is shown to be lower than the efficiency of all presented devices with graded Ga profile. This behavior is mainly caused by the low $\mathrm{V}_{\mathrm{OC}}$.

\subsection{Variation of Low Ga Plateau Length}

Starting from the Ga profile of sample number 4 (Figure 6(a)) which gives the best solar efficiency different lengths of the plateau were tested in order to understand its relevance in the solar cell performances. The different shapes of simulated compositional ratios are reported in Figure 7(a).

The simulated I-V curves obtained using the Ga profiles from Figure 7(a) are
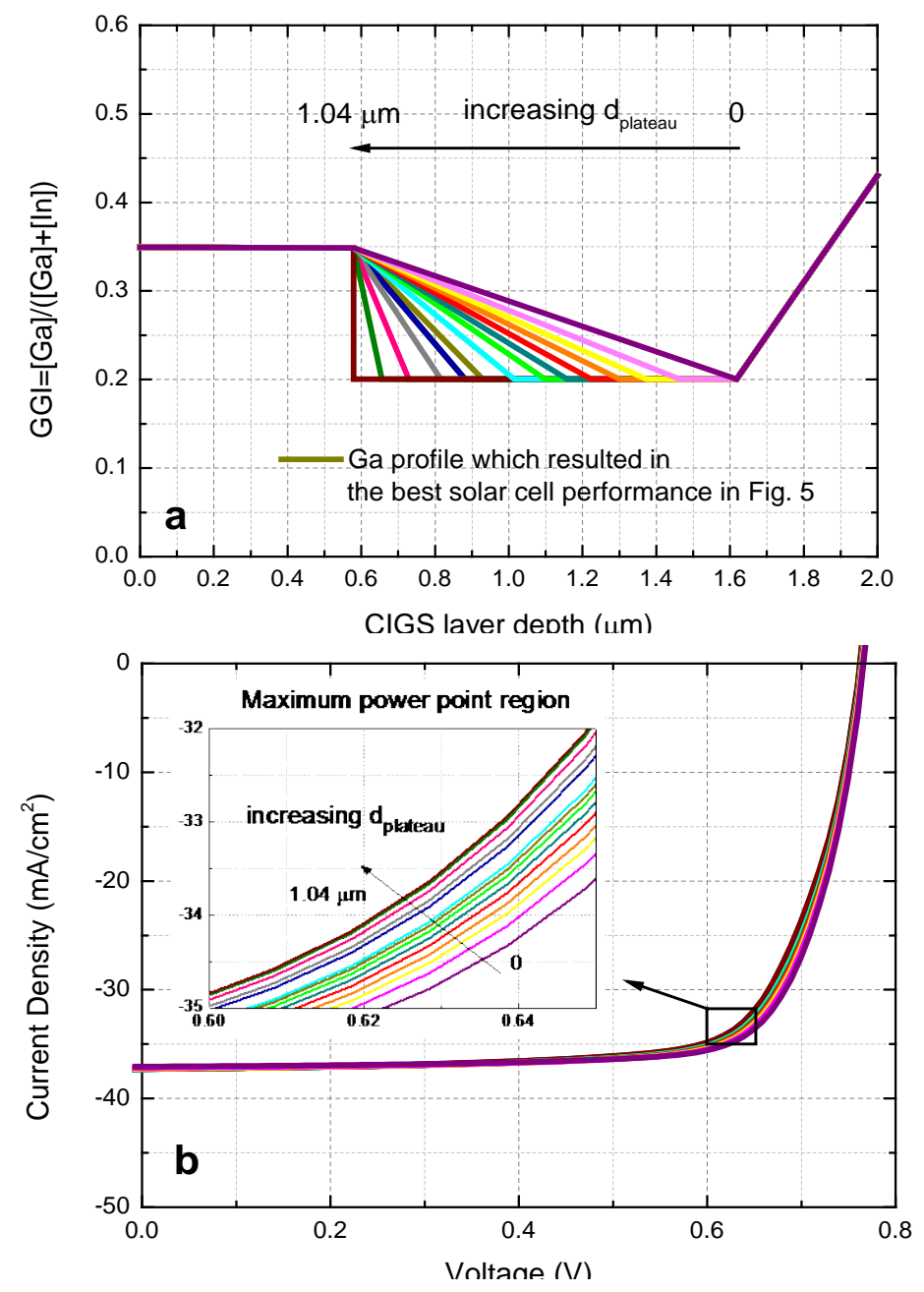

Figure 7. (a) Ga profiles implemented in the model in order to extract the most suitable length of the plateau for high efficient CIGS solar cell; (b) Simulated I-V curves obtained using the Ga profiles reported in Figure 7(a). 
presented in Figure 7(b). It can be seen that the differences in the solar cell performances, caused by the variation of the lengths of the plateau, are much less relevant than the front grading height. The best solar cell performance is reached for a minimum plateau length (the purple line of the Ga profile of Figure 7(a)); for higher GGI values of the plateau region the solar cell efficiencies are slightly decreasing. The changes in the solar cell efficiency values are less than $1 \%$ $\left(21.9 \%\right.$ for $\mathrm{d}_{\text {plateau }}=0,21.1 \%$ for $\left.\mathrm{d}_{\text {plateau }}=1.04 \mu \mathrm{m}\right)$. It can be concluded that the compositional ratio value at which the plateau is positioned has more impact on the cell efficiency than its length.

\subsection{Absorber Layer Thickness Variation}

Once the most suitable values and structure for the front grading height and the length and position of the plateau were established, the effect of decreased CIGS thickness on the cell performance was simulated. Thicknesses of 2, 1.7, 1.4, 1.1, $0.8,0.5$ and $0.2 \mu \mathrm{m}$ were considered. The Ga profile which has shown the best solar cell performances in the previous simulation was used $\left(\Delta y_{f}=0.22\right.$ and minimum $\mathrm{d}_{\text {plateau }}$ ). The simulated I-V curves are reported in Figure 8.

The best efficiency is obtained for a thickness of the absorber layer between 0.8 and $1.4 \mu \mathrm{m}$ that provide solar cells efficiency over $22.5 \%$, the gain in this range is also due to the beneficial effect of the grading at the back contact which becomes relevant. It can be seen that the simulated devices show almost constant high performance when an absorber layer between $0.5-0.8 \mu \mathrm{m}$ is used. On the contrary a significant drop of the efficiency is observed when the CIGS thickness is further reduced. FF slightly increases when reducing the thickness of the

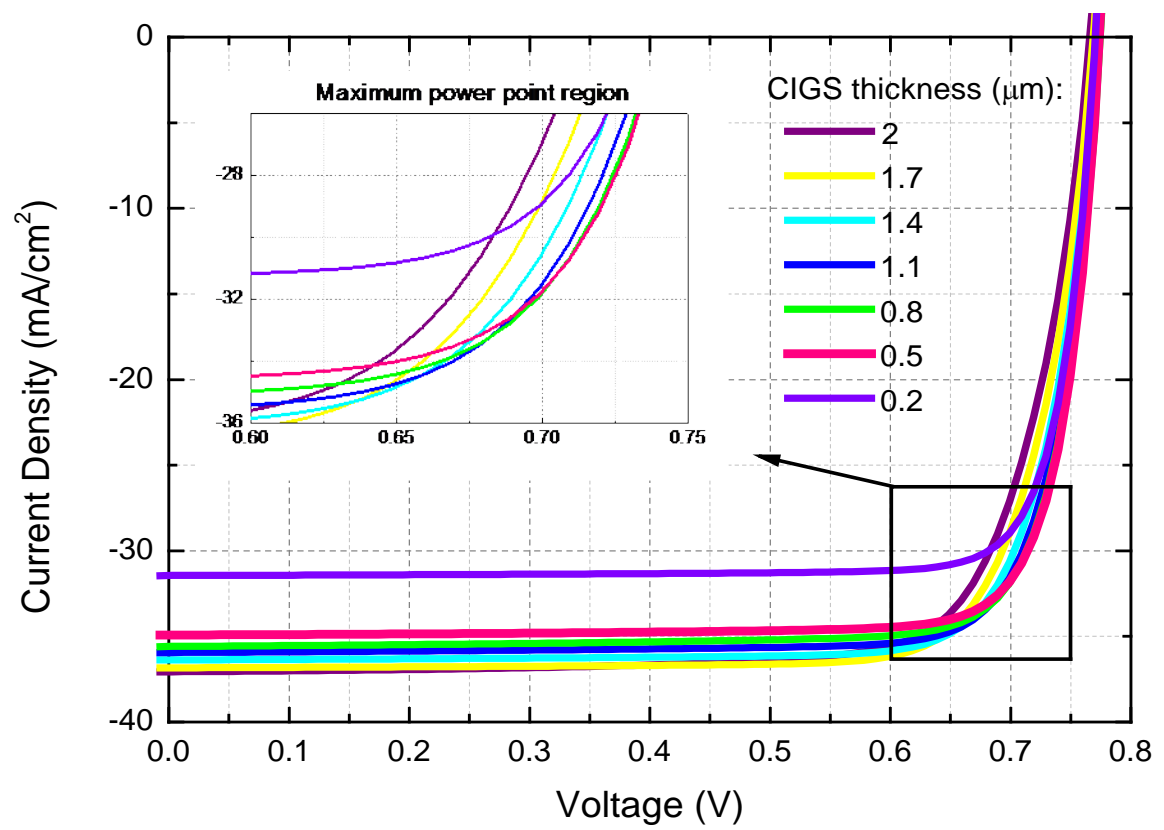

Figure 8. Simulated I-V curves for different thicknesses of the absorber layer, considering the Ga profile resulted in best solar cell performances reported in Figure 6. Zoom of the maximum power point region. 
absorber layer and $\mathrm{V}_{\mathrm{OC}}$ is almost not affected (a change less than $10 \mathrm{mV}$ has been obtained by simulations). The parameter which is the most influenced by the absorber thickness reduction is $\mathrm{J}_{\mathrm{SC}}$, which dramatically deteriorates when reducing CIGS thickness due to reduced absorbance. The simulations results are confirmed by the experimental studies presented in [34].

\section{Conclusion}

In this study, we investigated the effects of different Ga profiles on the electrical parameters of the CIGS solar cells. The aim of this work was to propose the most suitable double-grading profile in order to enhance the efficiency of the device. Our results show that an in-depth control of the front-grading is necessary in order to produce high-performing solar cell. The optimum forward double-grading needs to be confined in the SCR with a height $\Delta \mathrm{y}_{\mathrm{f}}$ equal to 0.22 . Higher values of $\Delta \mathrm{y}_{\mathrm{f}}$ bring to a deterioration of the cell performances due to the creation of a barrier for electron just behind the space charge region. Moreover, the simulations lead to the conclusion that a good control of the position of the plateau in the Ga profile is more important that the length of the plateau itself. The plateau needs to be positioned at compositional ratio value of GGI $=0.2$, in the area with the lowest defect density according to the trap model considered in the simulations. Furthermore, we showed that higher performances are reached when the CIGS thickness is reduced to $0.8-1.4 \mu \mathrm{m}$. In this thickness range device efficiencies higher than $22.5 \%$ were observed. These simulations results are of considerable relevance for the material optimization of the CIGS absorber layer.

\section{Acknowledgements}

This work has been supported by the Austrian Research Promotion Agency FFG through the project SynerCIS, project No. 840706, by the European Commission FP7-NMP Programme project SolarDesign, under the grant agreement No. 310220 and also by European Community's Framework Programme for Research and Innovation Horizon 2020 (2014-2020) project CABRISS under grant agreement no. 641972 .

\section{References}

[1] Green, M.A., Emery, K., Hishikawa, Y., Warta, W. and Dunlop, E.D. (2017) Solar Cell Efficiency Tables (Version 51). Progress in Photovoltaics: Research and Applications, 25, 668-676. https://doi.org/10.1002/pip.2909

[2] Green, M.A., Emery, K., Hishikawa, Y., Warta, W. and Dunlop E.D. (2015) Solar Cell Efficiency Tables (Version 46). Progress in Photovoltaics: Research and Applications, 23, 1-9. https://doi.org/10.1002/pip.2573

[3] Niki, S., Contreras, M. Repins, I., Powalla, M., Kushiya, K., Ishizuka, S. and Matsubara, K. (2010) CIGS Absorbers and Processes. Progress in Photovoltaics: Research and Applications, 18, 453-466. https://doi.org/10.1002/pip.969

[4] Liu, J., Zhuang, D., Luan, H., Cao, M., Xie, M. and Li, X. (2013) Preparation of 
$\mathrm{Cu}(\mathrm{In}, \mathrm{Ga}) \mathrm{Se}_{2}$ Thin Film by Sputtering from $\mathrm{Cu}(\mathrm{In}, \mathrm{Ga}) \mathrm{Se}_{2}$ Quaternary Target. Progress in Natural Science: Materials, 23, 133-138. https://doi.org/10.1016/j.pnsc.2013.02.006

[5] Lincot D., Guillemoles, J.F., Taunier, S., Guimard, D., Sicx-Kurdi, J., Chaumont, A., Roussel, O., Ramdani, O., Hubert, C., Fauvarque, J.P., Bodereau, N., Parissi, L., Panheleux, P., Fanouillere, P., Naghavi, N., Grand, P.P., Benfarah, M., Mogensen, P. and Kerrec, O. (2004) Chalcopyrite Thin Film Solar Cells by Electrodeposition. Solar Energy, 77, 725-737. https://doi.org/10.1016/j.solener.2004.05.024

[6] Kapur, V.K., Bansal, A., Le, P. and Asensio, O.I. (2003) Non-Vacuum Processing of $\mathrm{CuIn}_{1-\mathrm{x}} \mathrm{Ga}_{\mathrm{x}} \mathrm{Se}_{2}$ Solar Cells on Rigid and Flexible Substrates Using Nanoparticle Precursor Ink. Thin Solid Films, 431-432, 53-57.

https://doi.org/10.1016/S0040-6090(03)00253-0

[7] Lippold, G., Neumann, H. and Schindler, A. (2001) Ion Beam Assisted Deposition of $\mathrm{Cu}(\mathrm{In}, \mathrm{Ga}) \mathrm{Se} 2$ Films for Thin Film Solar Cells. Materials Research Society Symposia Proceedings, 668, H3.9.

[8] Ramanathan, K., Contreras, M.A., Perkins, C.L., Asher, S., Hasoon, F.S., Keane, J., Young, D., Romero, M., Metzger, W., Noufi, R., Ward, J. and Duda, A. (2003) Properties of 19.2\% Efficiency ZnO/CdS/CuInGaSe ${ }_{2}$ Thin-Film Solar Cells. Progress in Photovoltaics. Research and Applications, 11, 225-230. https://doi.org/10.1002/pip.494

[9] Gabor, A.M., Tuttle, J.R., Albin, D.S., Contreras, M.A., Noufi, R. and Hermann, A.M. (1994) High-Efficiency $\mathrm{CuIn}_{\mathrm{x}} \mathrm{Ga}_{1-\mathrm{x}} \mathrm{Se}_{2}$ Solar Cells Made from $\left(\operatorname{In}_{\mathrm{x}}, \mathrm{Ga}_{1-\mathrm{x}}\right)_{2} \mathrm{Se}_{3}$ Precursor Films. Applied Physics Letters, 65, 198-200. https://doi.org/10.1063/1.112670

[10] Marudachalam, M., Birkmire, R.W., Hichri, H., Schultz, J.M., Swartzlander, A. and Al-Jassim, M.M. (1997) Phases, Morphology, and Diffusion in CuInxGa1-xSe2CuInxGa1-xSe2 Thin Films. Journal of Applied Physics, 82, 2896-2905. https://doi.org/10.1063/1.366122

[11] Pettersson, J., Platzer-Björkman, C., Zimmermann, U. and Edoff, M. (2011) Baseline Model of Graded-Absorber $\mathrm{Cu}(\mathrm{In}, \mathrm{Ga}) \mathrm{Se}_{2}$ Solar Cells Applied to Cells with $\mathrm{Zn}_{1-\mathrm{X}} \mathrm{Mg}_{\mathrm{x}} \mathrm{O}$ Buffer Layers. Thin Solid Films, 519, 7476-7480. https://doi.org/10.1016/j.tsf.2010.12.141

[12] Lundberg, O., Edoff, M. and Stolt, L. (2005) The Effect of Ga-Grading in CIGS Thin Film Solar Cells. Thin Solid Films, 480, 520-525. https://doi.org/10.1016/j.tsf.2004.11.080

[13] Lundberg, O., Bodegård, M., Malmström, J. and Stolt, L. (2003) Influence of the $\mathrm{Cu}(\mathrm{In}, \mathrm{Ga}) \mathrm{Se}_{2}$ Thickness and Ga Grading on Solar Cell Performance. Progress in Photovoltaics. Research and Applications, 11, 77. https://doi.org/10.1002/pip.462

[14] Burgelman, M., Nollet, P. and Degrave, S. (2000) Modelling Polycrystalline Semiconductor Solar Cells. Thin Solid Films, 361-362, 527-532. https://doi.org/10.1016/S0040-6090(99)00825-1

[15] Ouédraogo, S., Zougmoré, F. and Ndjaka, J.M. (2013) Numerical Analysis of Copper-Indium-Gallium-Diselenide-Based Solar Cells by SCAPS-1D. International Journal of Photoenergy, 2013, 421076. https://doi.org/10.1155/2013/421076

[16] Chirilă, A., Buecheler, S., Pianezzi, F., Bloesch, P., Gretener, C., Uhl, A.R., Fella, C., Kranz, L., Perrenoud, J., Seyrling, S., Verma, R., Nishiwaki, S., Romanyuk, Y.E., Bilger, G. and Tiwari, A.N. (2011) Highly Efficient $\mathrm{Cu}(\mathrm{In}, \mathrm{Ga}) \mathrm{Se}_{2}$ Solar Cells Grown on Flexible Polymer Films. Nature Materials, 10, 857-861.

https://doi.org/10.1038/nmat3122 
[17] Jackson, P., Hariskos, D., Lotter, E., Paetel, S., Wuerz, R., Menner, R., Wischmann, W. and Powalla, M. (2011) New World Record Efficiency for $\mathrm{Cu}(\mathrm{In}, \mathrm{Ga}) \mathrm{Se}_{2}$ Thin-Film Solar Cells beyond 20\%. Progress in Photovoltaics. Research and Applications, 19, 894-897. https://doi.org/10.1002/pip.1078

[18] Hashimoto, Y., Kohara, N., Negami, T., Nishitani, N. and Wada, T. (1988) Chemical Bath Deposition of Cds Buffer Layer for GIGS Solar Cells. Solar Energy Materials and Solar Cells, 50, 71-77.

[19] Minemoto, T., Matsui, T., Takakura, H., Hamakawa, T., Negami, T., Hashimoto, Y., Uenoyama, T. and Kitagawa, M. (2001) Theoretical Analysis of the Effect of Conduction Band Offset of Window/CIS Layers on Performance of CIS Solar Cells using Device Simulation. Solar Energy Materials and Solar Cells, 67, 83-88. https://doi.org/10.1016/S0927-0248(00)00266-X

[20] Parisi, A., Pernice, R., Rocca, V., Curcio, L., Stivala, S., Cino, A.C., Cipriani, G., Di Dio, V., Galluzzo, G.R., Miceli, R. and Busacca, A.C. (2015) Graded Carrier Concentration Absorber Profile for High Efficiency CIGS Solar Cells. International Journal of Photoenergy, 2015, Article ID: 410549. https://doi.org/10.1155/2015/410549

[21] Pettersson, J., Torndahl, T., Platzer-Bjorkman, C., Hultqvist, A. and Edoff, M. (2013) The Influence of Absorber Thickness on $\mathrm{Cu}(\mathrm{In}, \mathrm{Ga}) \mathrm{Se}_{2}$ Solar Cells with Different Buffer Layers. IEEE Journal of Photovoltaics, 3, 1376.

[22] Wadaa, T., Kohara, N., Nishiwaki, S. and Negami, T. (2001) Characterization of the $\mathrm{Cu}(\mathrm{In}, \mathrm{Ga}) \mathrm{Se}_{2} / \mathrm{Mo}$ Interface in CIGS Solar Cells. Thin Solid Films, 387, 118-122.

[23] Kuo, S.-Y., Hsieh, M.-Y., Hsieh, D.-H. and Kuo, H.-C. (2014) Device Modeling of the Performance of $\mathrm{Cu}(\mathrm{In}, \mathrm{Ga}) \mathrm{Se}_{2}$ Solar Cells with V-Shaped Bandgap Profiles. International Journal of Photoenergy, 2014, Article ID: 186579. https://doi.org/10.1155/2014/186579

[24] Schroeder, D.J., Hernandez, J.L. and Rockett, A.A. (1997) Point Defects and Hole Transport in Epitaxial CuIn1-xGaxSe2. Proceedings of the 11th International Conference on Ternary and Multinary Compounds, Salford, 8-12 September 1997, 749-752.

[25] Song, S.H., Nagaich, K., Aydil, E.S., Feist, R., Haley, R. and Campbell, S.A. (2010) Structure Optimization for a High Efficiency CIGS Solar Cell. 35 th IEEE Photovoltaic Specialists Conference, Honolulu, 20-25 June 2010, 2488-2492.

[26] Song, J., Li, S.S., Huang, C.H., Crisalle, O.D. and Anderson, T.J. (2004) Device Modeling and Simulation of the Performance of $\mathrm{Cu}\left(\mathrm{In}_{1-\mathrm{x}}, \mathrm{Ga}_{\mathrm{x}}\right) \mathrm{Se}_{2}$ Solar Cells. Solid-State Electronics, 48, 73-79.

[27] Paulson, P.D., Birkmire, R.W. and Shafarman, W.N. (2003) Optical Characterization of $\mathrm{CuIn}_{1-\mathrm{x}} \mathrm{Ga}_{\mathrm{x}} \mathrm{Se}_{2}$ Alloy Thin Films by Spectroscopic Ellipsometry. Journal of Applied Physics, 94, 879-888. https://doi.org/10.1063/1.1581345

[28] Hanna, G., Jasenek, A., Rau, U. and Schock, H.W. (2001) High Quality Baseline for High Efficiency, $\mathrm{Cu}\left(\mathrm{In}_{1-\mathrm{x}}, \mathrm{Gax}\right) \mathrm{Se}_{2}$ Solar Cells. Thin Solid Films, 387, 71-72.

[29] Wei, S.H. and Zunger, A. (1995) Band Offsets and Optical Bowings of Chalcopyrites and Zn-Based II-VI Alloys. Journal of Applied Physics, 78, 3846. https://doi.org/10.1063/1.359901

[30] Gorji, N.E., Perez, M.D., Reggiani, U. and Sandrolini, L. (2012) A New Approach to Valence and Conduction Band Grading in CIGS Thin Film Solar Cells. International Journal of Engineering \& Technology, 4, 573-576.

[31] Herberholz, R., Nadenau, V., Rühle, U., Köble, C., Schock, H.W. and Dimmler, B. 
(1997) Prospects of Wide-Gap Chalcopyrites for Thin Film Photovoltaic Modules Solar. Energy Materials and Solar Cells, 49, 227-237.

[32] Dullweber, T., Rau, U., Contreras, M.A., Noufi, R. and Schock, H.-W. (2000) Photogeneration and Carrier Recombination in Graded Gap Cu(In,Ga)Se $e_{2}$ Solar Cells. IEEE Transactions on Electron Devices, 47, 2249-2254.

[33] Gloeckler, M. and Sites, J.R. (2005) Band-Gap Grading in $\mathrm{Cu}(\mathrm{In}, \mathrm{Ga}) \mathrm{Se}_{2}$ Solar Cells. Journal of Physics and Chemistry of Solids, 66, 1891-1894. https://doi.org/10.1016/j.jpcs.2005.09.087

[34] Lundberg, O., Bodegaerd, M., Malmstroem, J. and Stolt, L. (2003) Influence of the $\mathrm{Cu}(\mathrm{In}, \mathrm{Ga}) \mathrm{Se}_{2}$ Thickness and Ga Grading on Solar Cell Performance. Progress in Photovoltaics, 11, 77-88. https://doi.org/10.1002/pip.462 